\title{
The Certainty and Scope of Knowledge: Bonaventure's Disputed Questions on the Knowledge of Christ
}

\author{
ANDREAS SPEER
}

I shall be concerned here with two key questions for any theory of knowledge: (1) Is there such a thing as certainty of knowledge and, if so, what is it? (2) How far does our knowledge extend, and what are its possible limits? In answering these questions I shall make use of Bonaventure's seven disputed questions concerning the knowledge of Christ. This procedure surely calls for some explanation, since both the author and the subject matter of these questions seem to fall outside the sphere of philosophical interest. As far as Bonaventure's philosophical importance is concerned, there still seems to be widespread agreement with Etienne Gilson's judgment that, in contrast to Albert the Great or Thomas Aquinas, Bonaventure has nothing that can properly be called philosophy, if by 'philosophy' one means the discoveries of reason alone, independent of the data of revelation. ${ }^{1}$ Is not this caveat borne out in the very subject matter of these disputed questions? What can reason alone tell us about the knowledge of Christ?

1. Etienne Gilson, La philosophie de Saint Bonaventure, 3d ed. (Paris: Vrin, 1924), p. 387. 
If, heedless of such considerations, I persist in using Bonaventure to address one of the great questions of philosophy, it is because I am convinced that one can identify in this text an original philosophical contribution to the two questions I posed at the beginning of this paper. To see this, one must first reconstruct the context of the question; in doing so I intend to proceed historically. I shall then focus on the systematic meaning of Bonaventure's answer. Finally, the historical dimension will come back in view when I relate this answer to Bonaventure's work as a whole.

\section{THE HISTORICAL CONTEXT}

The Quaestiones disputatae de scientia Christi lead us immediately to Bonvaventure's time in Paris. They mark a temporary peak in a typical academic career of that day, a career that Bonaventure began in 1235 as a student in the Faculty of Arts and that reached a provisional climax with the licentia docendi and Bonaventure's appointment in 1254 as ordinary regent master in the Faculty of Theology. ${ }^{2}$ When he went to Paris in 1235 , Bonaventure encountered a university already thirty-five years old and undergoing a stormy period in its development. The founding of the university at Paris was itself an expression of a development with large consequences. It led, among other things, to a reorganization of teaching, which was now to be done in a thoroughly "scholastic" or school-ish fashion. ${ }^{3}$ This process, begun in the twelfth century, led eventually to a progressive dissolution of the classical canon of instruction comprising the seven liberal arts and theology. Moreover the unity of faith and reason, which had, as Christian doctrine, earlier been able to meet the need for a comprehensive and persuasive interpretation of the world, now came apart. 4

2. Jacques-Guy Bougerol, Introduction à Saint Bonaventure, rev. ed. (Paris: J. Vrin, 1988), pp. 3-4 and 13-14; Fernand Van Steenberghen, La philosophie au XIIle siecle (Louvain: Publications universitaires, and Paris: Béatrice-Nauwelaerts, 1966), pp. $193 \mathrm{ff}$.

3. See for an overview of this point Joseph Koch, "Scholastik," in Religion in Geschichte und Gegenwart 5:1494-1498.

4. Wolfgang Kluxen, "Der Begriff der Wissenschaft," in Die Renaissance der Wissenschaften im 12. Jahrhundert, ed. Peter Weimar, Zürcher Hochschulforum 2 (Zurich: 
When the young Giovanni Fidanza went to Paris in 1235 as a student, just four years had passed since the papal letter of 13 April 1231. With it, Gregory IX had managed to put an end to the fighting at the University of Paris aroused by his letter of 1228 to the professors of the theological faculty. At issue were both the use of speculative method and the employment of philosophical expressions and concepts in the exposition of the doctrine of the faith. The controversies were ignited principally by the employment of Aristotle's writings, especially of the so-called libri naturales, in philosophical and theological instruction. ${ }^{5}$ The libri naturales had already been condemned in 1210 by the decrees of a regional synod of Sens under Peter of Corbeil, Archbishop of Paris. The synodal prohibition was directed in particular against the alleged heresies of Aumary of Bene and David of Dinant, but in August 1215 it entered the new university statutes of the Faculty of Arts, which permitted instruction in Aristotle's logical and dialectical writings but not in the "libri Aristotelis de methaphisica et de naturali philosophia." 6 The effect of the prohibition was minimal, as the intervention of Gregory IX indicates. The pope himself was finally compelled to open a way to the study of Aristotle's writings on natural philosophy and metaphysics.

One would not do justice to the situation at the beginning of the thirteenth century if one were to see in these conflicts merely a power struggle between the Church's magisterium and the university. Gregory IX had himself studied theology in Paris. Like Innocent III, who was involved in the dispute over the statutes in 1215, Gregory had been a student of Peter the Chanter, who was master of theology at Notre Dame from about 1170 until his death in 1197. The conflicts had rather to do with a question of fundamental importance. Theology faced the challenge of determining afresh its position in connection with the new understanding of science. In place of the

Artemis, 1981), pp. 273-293; and Georg Wieland, Ethica-scientia practica: Die Anfänge der philosophischen Ethik im 13. Jahrhundert, BGPTM NS 21 (Munster: Aschendorff, 1981), pp. 9-18; and Speer, "Wissenschaft und Erkenntnis: Zur Wissenschaftslehre Bonaventuras," Wissenschaft und Weisheit 49 (1986): 169ff.

5. For an overview, see Van Steenberghen, La philosophie au XIIIe siècle, pp. 100110.

6. Chartularium Universitatis Parisiensis, ed. Heinrich Denifle and Emile Chatelain (Paris: Frères Delalain, 1889), 1:78-79, no. 20; Van Steenberghen, La philosophie au XIIle siècle, pp. 89-99. 
"holy relevance" of studies directed towards the better understanding of revelation, there now comes amor scientiae, scientific knowledge in accordance with rational principles, pursued for its own sake. Theology became a science among sciences, its status determined under universal notions. With that displacement came the question of the relationship between scientific rationality and the revealed truths of salvation.?

\section{THE THEOLOGICAL QUESTION}

For his first great disputation after becoming ordinary master, Bonaventure chose the question of Christ's knowledge (November 1253-spring 1254). He had already treated it once before in the context of his lectures on the Sentences. ${ }^{8}$ But in his lectures he had been bound by the program of the Sentences, of the anthologized authorities obligatory for all commentators. In the Quaestiones disputatae de scientia Christi, we have Bonaventure's independent and systematic grappling with this topic, one chosen by him as suitable to solemn public disputation.

With his choice of topic, Bonaventure seizes an obviously theological problem, the question of Christ's knowledge. This question may now seem academic, but properly considered it leads to a host of theologically and philosophically important issues. To see the philosophical significance, one must first discuss the theological content, which results from the teaching on the hypostatic union by the Council of Chalcedon (451). The dogmatic exposition of the council, that Jesus Christ was one single person, perfect in Godhead and perfect in humanity, formed the provisional endpoint in a struggle that defined

7. Albert Zimmermann, "Die Theologie und die Wissenschaften," in Die Renaissance der Wissenschaften, pp. 87-93; Kluxen, "Der Begriff der Wissenschaft," pp. 281283; Joachim Ehlers, "Monastische Theologie, historischer Sinn und Dialektik: Tradition und Neuerung in der Wissenschaft des 12. Jahrhunderts," in Antiqui und Moderni, ed. Albert Zimmermann, Miscellanea Mediaevalia 9 (Berlin and New York: W. de Gruyter, 1974), pp. 58-62.

8. For the dating, see Bougerol, Introduction, pp. 4-6. For the earlier treatment, see Bougerol, p. 201, and Bonaventure Sent. 3.14 as in Opera omnia 3, ed. CSB (Quaracchi: CSB, 1887) 295a-326b. 
the first centuries of Christianity-the struggle over the mystery of the hypostatic union, which stands at the center of Christian belief about the redemption. ${ }^{9}$ The redemption can be thought of as a perfection immanent in a human being only if Jesus Christ is truly human, but it can have universal efficacy only so far as he is also truly God.

If one refuses to leave this as just a paradox, accepted on faith but ultimately intractable to theological reasoning, a host of problems arises from the teaching that Christ has two natures. These problems determined the rapidly evolving dogmatics of the centuries following Chalcedon. How can this union of the two subsistent natures in one person or hypostasis be conceived, when according to the classic formulation of Lateran IV (1215) the distance between Creator and creation is so great that any similarity grounded in the act of creation is conditioned by a far greater dissimilarity? Again, how can one conceive the participation of the human nature in the divine? This second question has wide implications for the problem of the hypostatic union and leads into the deeper realm of the possibilities for philosophicaltheological affirmation. The same is true of the question about how properties and attributes can be predicated of this one person. The unity of the person should not be lost from one side or the other, nor can there be an inadmissible exchange of properties (idiomata) between the natures that are bound together, though never confused, in Christ-even though these properties can be common to the person or hypostasis as their underlying subject. Over the course of the history of theology, basic rules covering the so-called "communication of idioms" were laid down. These were supposed to help preserve the hard-won Christological via media that had been achieved by the orthodox councils. ${ }^{10}$

The seventh disputed question about the knowledge of Christ provides a clear example of this logically engrossing problem. Does the human soul of Christ understand all divine judgments? Does it

9. Herbert Vorgrimler, "Hypostatische Union," LTK 5:579-584; Rowan Williams, "Jesus Christus, II: Alte Kirche," TRE 16:726-745, especially pp. 734-742; Alain Michel, "Hypostatique (Union)," DTC 7:437-568.

10. Karl Forster, "Idiomenkommunikation," LTK 5:607-609; J. F. Rigney, "Communication of Idioms," NCE 4:35-37; A. Michel, "Idiomes (Communications des)," DTC 7:595-602; Arthur M. Landgraf, Dogmengeschichte der Frühscholastik, 2: Die Lehre von Christus (Regensburg: F. Pustet, 1953) 1:138-146. 
possess all the knowledge of the divine Word that is united to it? And does it possess it so far as Christ is a human being? The rules for discourse about the communication of idioms, which Bonaventure invokes when replying to the objections raised, help him to grasp the issue. This issue does not consist in the one hypostasis that can bear diverse attributes, but rather in the ordering of the attributes-in this case, of knowledge- to the two natures, because no simple exchange of attributes is admissible. ${ }^{11}$

But then how are we to think of the psychological unity of Christ? Anselm gave this question prominence in Cur Deus homo. After him, under the influence of Abelard and Hugh of St. Victor, among others, the emphasis was all on the perfection of Christ's human knowledge. 12 This emphasis remains important for Bonaventure's posing of the question. He learned it in detail from his teacher, Alexander of Hales. Alexander treated the matter in his Gloss on the Sentences, in the Summa attributed to him, and in a disputed question of his own. He concluded in all three that Christ had in God a perfect knowledge of God and the world, and had a perfect knowledge of things by means of himself. Thus, Christ's human nature has genuine knowledge of its own. ${ }^{13}$ In terms of the psychology of knowledge, Alexander teaches, in harmony with the Augustinian tradition, that God is both the first-known (primum cognitum) and the psychologically first source of knowledge about the world. 14

The question of the relative independence of the human being begins to carry more weight within the context of Aristotelian psychology, since the Aristotelian doctrine of the active and possible intellects seems to preclude every priority of divine illumination. Hence, the need for a new psychological and epistemological grounding for the originally theological thesis that God is first known. He is first in

11. De scientia Christi 7 ob. 1-3 and ad 1-3 (CSB 5:37a-b, 40b).

12. Jan Th. Ernst, Die Lehre der hochmittelalterlichen Theologen von der vollkommenen Erkenntnis Christi, Freiburger theologische Studien 89 (Freiburg: Herder, 1971), pp. 53-96. See also Landgraf, Dogmengeschichte der Frühscholastik, 2: Die Lehre von Christus, 2:44-68.

13. Alexander of Hales Glossa in Sent. 3.13.10-3.14.24 (3:131-149), and Alexander Quaestiones disputatae "antequam esset frater" 42 (2:414-730). Compare the Summa "fratris Alexandri" 3.3.2 (4:163-171). See also Ernst, Erkenntnis Christi, pp. 113-129.

14. Ernst, Erkenntnis Christi, pp. 151-153. 
regard to his noetic priority and in regard to human knowledge of the world, for which the human being's relation to the world must also be taken into account.

\section{THE SOUL OF CHRIST AS MODEL}

Against such a complex background, one can begin to appreciate the interest that moved Bonaventure to take up, again, the question of Christ's knowledge. He could now take it up on his own terms and so use the series of disputed questions to go far beyond the answers permitted by the limits of a commentary on Sentences 3.

In the fourteenth distinctio of that book, Bonaventure poses the questions in the way laid out for him by the authorities. He traces this way in the divisio textus on the problem of Christ's omnipotence and omniscience. ${ }^{15} \mathrm{He}$ finally reaches the overarching issue of this distinctio, the question of the perfection of the knowledge that Christ's soul possessed eminently. He unfolds the issue in three articles of three questions each. Much rests on the distinction in the knowledge that Christ's soul had about the divine Word (de Verbo), in the divine Word (in Verbo), and from the divine Word (a Verbo). Bonaventure discusses all three kinds of knowledge in relation to the divine Word, which the prologue to the Gospel of John describes as the exemplary prototype of all that is (1:3). Thus there is self-knowledge in Christ (de Verbo) as well as his knowledge of things in their actual and exemplary being (in Verbo), and also the perfection of that knowledge in omnipotence and omniscience ( $a$ Verbo).16

If one can already discern here that Bonaventure is less interested in psychological than in epistemological issues, the structure of the seven disputed questions de scientia Christi makes it altogether clear that the question of Christ's knowledge cannot be treated even theologically outside an epistemological horizon. Indeed, one can get the well-founded impression that it is precisely the epistemological implications of the question about Christ's knowledge that enticed

15. Sent. 3.14.1-2 and divisio textus (CSB 3:283a-294b and 295a-b).

16. Sent. 3.14.1-3 (CSB 3:294a-325b). Compare Ernst, Erkenntnis Christi, pp. 144-160. 
Bonaventure to treat the question so thoroughly. This is shown both by the polished and well-developed lines of argument in the epistemologically significant questions, especially the fourth, and by the systematic attack, which differs from that in the commentary on the Sentences. Consider the order of questions: ${ }^{17}$

1. Does the knowledge of Christ, so far as he is the divine Word, actually extend to the infinite?

2. Does God know things by means of their Ideas or by means of their essence ("per essentiam")?

3. Does God know things by means of Ideas that really differ from one another?

4. Is what is known by us with certainty known in the eternal Ideas themselves?

5. Was the soul of Christ wise only through the uncreated wisdom, or wise through both created and uncreated wisdom?

6. Did the soul of Christ grasp uncreated wisdom itself?

7. Did the soul of Christ grasp everything that uncreated wisdom grasps?

I have indicated the obvious division into three parts. Christ's divine knowledge is the point of departure in the first three questions. What does this knowledge include? How does it proceed? In what manner does it concern itself with things, and how are they contained in it? We shall return at greater length to the metaphysical background of these questions.

There follows in the fourth question the hinge of the whole collection. In its very articulation, the epistemological interest becomes unmistakably clear. The same is true of the central point of that epistemology, the problem of the certainty of knowledge. Bonaventure sets up the twofold criterion of infallibility on the part of the subject and of the object. ${ }^{18}$ How can one know with certainty what something is?

17. I have just published a new edition based on the Quaracchi-text with a German translation, corrective notes, and a detailed introduction (Hamburg: F. Meiner, 1992).

18. Scientia Christi 4 (5:23b): "cognitio certitudinalis esse non potest, nisi sit ex parte scibilis immutabilitas et infallibilitas ex parte scientis." 
By knowing it completely, that is, under all the conditions that cover both object and subject. As Bonaventure says elsewhere, appealing to Aristotle, "For it is then that we know, namely, when we believe that we know the reason why a thing is, and when we know that it is impossible that the thing be otherwise." 19

The next three questions pursue this issue. They discuss the possibility that Christ's soul grasped wisdom perfectly. But in the Augustinian tradition 'wisdom' is the usual name for the epitome of perfect knowledge, and thus for a knowledge that has a perfect grasp of the conditions under which it exists. ${ }^{20}$

Thus, Bonaventure can take Christ's soul as the model when he discusses comprehensively the conditions of knowledge and of science, bringing together into systematic form elements that appeared at various points when commenting on the Sentences. Among the more significant of these points, in addition to 3.14, are 1.35 (on God's knowledge in itself and in general) and 1.43 (on the divine power with regard to illimitability). Both distinctions from the first Book disclose an eminently epistemological interest. ${ }^{21}$ The theological implications of the question of Christ's knowledge are always developed against a philosophical background.

Bonaventure himself hands us this key to interpreting the questions concerning Christ's knowledge in their epilogue. He points out retrospectively that from everything "which has been said and determined about the wisdom of Christ with respect to both the divine and the human nature, there can be seen the manner of knowing both in the knowledge of the Creator and in the knowledge of the creature, not only in the fatherland, but even in the pilgrim state"-not only in the state of perfection, but even under the present conditions of mortal

19. Christus unus omnium est magister 6 (5:568b-569a): "Tunc enim scimus, cum casum arbitramur cognoscere, propter quam res est, et scimus, quoniam impossibile est aliter se habere."

20. See Tilman Borsche, Was etwas ist: Fragen nach der Wahrheit der Bedeutung bei Platon, Augustinus, Nikolaus von Kues und Nietzsche (Munich: Fink, 1990), p. 113. But compare to this Aristotle's remarks on knowledge as episteme of causes (aitias) and principles (archas) in Metaphysics 1.2 (982a4-6). On the question of the certainty of knowledge, see further Speer, Triplex veritas: Warheitsverständnis und philosophische Denkform Bonaventuras, Franziskanische Forschungen 32 (Werl/Westf.: Dietrich Coelde, 1987), pp. 54-56.

21. Sent. 1.35 (CSB 1:599a-616b), 1.39 (1:684a-699b), and 1.43 (1:763-778). 
existence. ${ }^{22}$ This statement is worth unfolding more closely, using as a guide the individual questions.

\section{EXEMPLARISM}

The issue of the first question arises on the doctrine, which goes back to Augustine, that God's knowledge is the original principle of everything that is. It includes everything actual and everything possible, since God alone, "by beholding himself as truth, knows the entire truth." God alone can, therefore, simply abstract from every cause, for he is ultimately the cause of all that is. ${ }^{23}$ But things must not be considered only in themselves and their own causality, in their own species, but also in their exemplarity, in their essential relatedness to the ultimate creative cause. ${ }^{24}$ This cause lies in God's knowledge, the creative principle of the existence and intelligibility of all creatures. God's knowledge in the "exemplary forms" (formae exemplares) and according to the "eternal ideas" (sempiternae rationes) describes at once the ontological distance and the ontological proximity of Creator and creation. It also suggests the gnoseological consequences. ${ }^{25}$

That is the subject of the second question. The eternal ideas cannot be the true essences (essentiae) and quiddities (quidditates) of things, since the eternal ideas cannot be separated from the Creator. "Creator and creature necessarily have different essences." 26 The principal concepts through which Bonaventure attempts to describe adequately the relationship between Creator and creature are similitudo, assimilatio, expressio, exemplaritas, and repraesentatio. This group of terms poses many problems for translation, and any particular rendering will depend on the context. But Bonaventure maintains consistency of meaning throughout, as becomes clear in the following example.

In the conceptual field of exemplarism, there stands out one concept that is peculiarly suited to encompass all significant aspectssimilitudo. Similitudo describes a relation, indeed an immediate and

22. Scientia Christi epilogue (CSB 5:42b).

23. Scientia Christi 1 (CSB 5:5a-b).

24. Sent. 1.39.1.1 ad 3 (CSB 1:686b).

25. Scientia Christi 2 (CSB 5:8b); compare Speer, Triplex veritas, p. 102.

26. Scientia Christi 2 (CSB 5:8b). 
simple relation between two relata that are related to each other. "One is the image of the other" (unum est similitudo alterius), without its being the case that a third relatum forms the actual standard for this relation. ${ }^{27}$ This relation of likeness can now be read in two directions by applying the ontological relationship of created beings to their creative origin. "[O]n the one hand as imitative likeness (similitudo imitativa), as the creature is the likeness of the Creator (similitudo Creatoris); on the other hand as likeness of the prototype (similitudo exemplativa), as the prototypical standard and likeness (ratio exemplaris et similitudo) of the creature is in the Creator."28

This ontological distinction has as its epistemological corollary the distinction between knowledge that is caused by things (notitia causata a rebus) and knowledge that is itself the cause of things (notitia causans res). The creature's capacity for knowledge is actualized by principles exhibited in reality; the relation between knower and known is therefore similitudo imitativa. The divine intellect, by contrast, holds the principles of knowledge in itself. It compares them with what exists because, as similitudo exemplativa, it is truth able to express itself, the expressive principle of the existence and intelligibility of everything that is ("sua summa veritate omnia aeternaliter exprimens"). ${ }^{29}$ The exemplarity of God, thus, guarantees the truth of what exists, because what exists is first exemplified in the summa veritas. If it is known that this highest truth exists, then the identity of the order of knowledge and the order of being is also known. Bonaventure attempts such a proof in several places by trying to show that the denial of a highest truth, in fact, presupposes the existence of such a performative contradiction, or that the notion of highest truth once understood includes the existence of that truth (the ratio Anselmi). ${ }^{30}$ Here one sees the systematic place of the thesis that God is the first known.

At this point, however, there also appears the crucial difference between Bonaventure's understanding of exemplarism, as decisively

27. Scientia Christi 2 (CSB 5:9a).

28. Scientia Christi 2 (CSB 5:9a). Compare Speer, Triplex veritas, pp. $102 \mathrm{f}$.

29. Scientia Christi 2 (CSB 5:9a).

30. Scientia Christi 4.12 (CSB 5:18b), 6.5 (5:34a), 4 ad 16 (5:25b), 4 ad 23-26 (5:26b-27b). See also Coll. in Hexaëmeron 4.1 (5:349a) and Speer, Triplex veritas, pp. $46-48$. 
shaped by Augustine, and Platonic or neo-Platonic exemplarisms. The divine prototype does not stand on the summit of a pyramid of being that results from a process of emanation. Rather, as the archetypal expression of the divine ground, as the everlasting Word, the divine prototype is equally immediate to each of its creaturely images. Conversely, things not only possess a meaning in themselves, they bring to mind as creaturely copies the divine original "penes modum repraesentandi." 31 The creature is God's trace (vestigium), image (imago), and likeness (similitudo). Thus, as Bonaventure says in the body of the fourth question, "every creature is a trace because it is from God, an image when it knows God, a likeness so far as God dwells in it. From this threefold gradation of relationship there follows a threefold gradation of divine cooperation."32

\section{CERTAINTY OF KNOWLEDGE AND THE DOCTRINE OF IDEAS}

The intelligibility of things corresponds to their ontological structure. For Bonaventure, as we have seen, all knowledge lies under the postulate of certainty, which is necessarily valid on account of the excellence of knowledge and the worthiness of the knower. ${ }^{33}$ But how can this requirement be met? At the beginning of the fourth question, Bonaventure discusses two positions, both of which seem to him inadequate, indeed erroneous. It is not the case that certain knowledge can exist only in the intelligible world of the eternal prototypes, nor can one speak of a mere influence on knowing of the eternal standard (ratio aeterna) without its being the case that the eternal standard itself could be reached. ${ }^{34}$

Created truth (veritas creata) is not simply unchangeable, it is unchangeable only in consequence of a fundamental condition. So Bonaventure seeks a third way between the two rejected positions. "In order to achieve with necessity a knowledge that lays claim to

31. Sent. 1.3.1.1.2 ad 4 (CSB 1:73a); Speer, Triplex veritas, pp. $105 \mathrm{f}$.

32. Scientia Christi 4 (CSB 5:24a).

33. Scientia Christi 4 (CSB 5:23b).

34. Scientia Christi 4 (CSB 5:23a). 
certainty, there is sought an eternal standard to guide and drive-not by itself and in its perfect clarity, but together with a created standard, and in such a way that it is to some degree seen by us even in the state of imperfection." 35 This eternal standard is the ars aeterna, the eternal creative art, in which things are considered according to their conceptual and specific mode of existence.

This complex sphere of the ars aeterna, which mediates the orders of being and knowledge, usually appears philosophically in connection with the question of Bonaventure's theory of ideas. The idea has the function of a twofold principle of mediation: it betokens on the level of being the relation of creaturely reality to its creative source; and it shows on the level of knowledge the relationship between subject and object. ${ }^{36}$

Following Augustine, Bonaventure places the source of the ideas in God's knowledge. God, knowing himself, turns upon his own being and expresses himself in his eternal Word. ${ }^{37}$ The ideas, thus, participate in God's essence and the mode of his own thinking. With reference to our knowledge, the idea is the "standard of knowledge" (ratio cognoscendi). ${ }^{38}$ As regula, norma, or lex, the highest truth becomes in the idea the norm for the knowing intellect in regard both to immutability and causation; it is the eternal standard that regulates and sets in motion ("ratio aeterna ut regulans et ratio motiva"). ${ }^{39}$ But while the idea as standard of the divine knowledge is an expression of God's creative knowledge (similitudo expressiva), in relation to the human intellect it betokens a relationship of similarity as guarantor of knowledge (similitudo impressa). What is known is the truth itself, even if mediated by the idea. The creative act of the rational creature is to follow this standard of knowledge, without in any way constituting it. 40

35. Scientia Christi 4 (CSB 5:23b).

36. See Sent. 1.35.1.3 (CSB 1:608a).

37. Scientia Christi 3 (CSB 5:13b-14a), 4.23-27 (5:19b-20a, "rationes Augustini"). Compare the entry "Idee" in Historisches Wörterbuch der Philosophie 4:63-65 and 4:87f. The classical Augustinian source is De diversis quaestionibus 83 46.1-2 (CSEL 44A:70.1-73.73).

38. Compare Sent. 1.35.1.1 (CSB 1:601a).

39. Scientia Christi 4 (CSB 5:23b).

40. Sent. 1.35.1.1 (CSB 1:601b). 
For the doctrine of ideas thus conceived, there arises now, as a special problem, the multiplicity of ideas. How can this multiplicity, which serves as pattern for classes and individuals alike, be conceived in relation to God's unity? On the one hand, it cannot be that "to produce a human being is to produce an ass." On the other hand, the multiplicity of appearances cannot import any real multiplicity into God's being. ${ }^{41}$ Bonaventure tries to solve this problem by referring to two different moments in the idea. As an expression of the divine creative power, the idea stands more to God's side; as constitutive element of our knowledge, it is more strongly present in the being known now. But since God, in reality, does not turn towards anything other than himself, the ideal standards in God cannot be thought of as a real multiplicity (secundum rem), but only as a conceptual one (secundum rationem). "[T]he concept arises not only from the side of the knower but also from the side of the object known." 42 That is how the ideas, so far as they are standards of knowledge (secundum rationem intelligendi), can denote what is really distinct. The unity-inreality is the expression of the unity of the one divine truth in itself and with itself. It can express and represent the entire multiplicity of actual and possible reality. The plurality for knowledge, on the other hand, is an expression of the kind and manner of our intellectual participation in the one divine truth. "If the many ideas therefore also possess a unity in fact (re), so that they can be called the one truth and the one divine Word, they can nevertheless possess no unity according to their meaning (ratione) so that one could speak of several ideas or standards (ideae vel rationes) as a single idea or standard." 43 For the human intellect, then, the multiplicity and diversity of ideas represents itself as a reality. It denotes ad modum rei the concrete way-of-being of things. 44

The difficult problem of the unity and plurality of ideas is reflected in Bonaventure's terminology, which is by no means completely consistent. Whereas idea, ratio, and similitudo are used in both singular and plural, exemplar, ars, and verbum are spoken of only in the singular. Ratio and idea apply primarily to things in their distinctness, while

41. Scientia Christi 3 (CSB 5:14a).

42. Scientia Christi 3 (CSB 5:14a).

43. Scientia Christi 3 ad 19 (CSB 5:16b).

44. Scientia Christi 3 ad 2 (CSB 5:14b). 
the remaining concepts relate the multiplicity of things to their first principle as source and goal. 45

It is now clear why Bonaventure must reject the extreme positions cited at the beginning. He thinks that they lead to skeptical aporia, to the conclusion "that one can know absolutely nothing." 46 Beyond the a priori moment, an a posteriori or empirical moment is indispensable for the achievement of knowledge, and conversely. In order to know, the intellect must not only turn itself toward the rationes aeternae, but also proceed from the essences abstracted from experience. 47 The ideas are not the obiectum quod of human knowledge, but only the obiectum $q u o$, through whose influence we attain certainty. Consequently, the ideas can only be grasped reflexively by the human intellect. As formal principles of knowing, they first guarantee certainty on the part of both the objects and subjects of knowledge. But the specifying properties and material principles arise out of experience. ${ }^{48}$ One sees here the influence of the Aristotelian theory of knowledge. Bonaventure discusses it thoroughly in the opposita of the fourth question and rehearses it again in the following answer. ${ }^{49} \mathrm{He}$ arrives thus at a distinctive solution that thoroughly modifies the Augustinian conception.

\section{CERTAINTY AND ILLUMINATION}

The so-called "theory of illumination" both derives from Augustine and is much modified from Augustine. This doctrine allows us to summarize, under the guidance of the fourth question, the answers that were developed by using exemplarism and the theory of ideas, as it allows us to bring them to bear on the following questions. For Bonaventure, too, light is a "metaphysical conjecture" for truth as well as a "model" for the relation between unity and plurality, between

45. See on this point Sent. 1.35.1.3 ad 2 (CSB 1:608b) and Speer, Triplex veritas, pp. $99 f$.

46. Scientia Christi 4 (CSB 5:23a).

47. Scientia Christi 4 (CSB 5:24b).

48. Scientia Christi 4 (CSB 5:23b-24a); Speer, Triplex veritas, p. 101.

49. See especially Scientia Christi 4 ob. 7-16 (CSB 5:21b-22a) and the corresponding replies, ad 7-16 (5:25a-b). 
the absolute and the conditioned, between source and descendant. ${ }^{50}$ In order to illustrate this, he takes over from Augustine the example of the godless person who can think a concept like eternity and judge rightly regarding rules of practical living because in doing so "he turns himself to that light by which he is always touched, even when he turned himself away from it." 51

Behind this, the problematic of certainty appears once more, for Bonaventure sees, with Augustine, the cause of the pagan's knowledge in rules "that are written down in the book of that light which is called Truth." 52 These rules are obviously in force quite independently of the mistakes of the knower and the always deficient objects known. The metaphor of "illumination" emphasizes the non-empirical origin of the judgments, which do not have their origin in experience and are not the outcome of a process of abstraction. Although Bonaventure requires, for full knowledge, a tracing back "to an altogether unchangeable and fixed truth as well as to an altogether infallible light," the influence of the light cannot be seen only as general, as if both knowledge and wealth were indebted to that influence in the same manner; nor can it be seen only as special, as if all knowledge were infused and no knowledge were acquired or innate. ${ }^{53}$ Thus, the epistemological problematic in the theory of illumination becomes noticeably stronger when focused on the individual subject. How are we to conceive concretely of the cooperation of the infallible light of truth, especially since Bonaventure does not fundamentally reject the Aristotelian arguments, but seeks instead to integrate them into his own theory of knowledge? 54 The distinction between a created standard (ratio creata) and an eternal standard (ratio aeterna), between the light of the creature (lux creaturae) and the infallible light (lux infallibilis), between a lower reason (ratio inferior) and a higher reason

50. Hans Blumenberg, "Licht als Metapher der Wahrheit," Studium Generale 10 (1957): 432; Klaus Hedwig, Sphaera lucis: Studien zur Intelligibilität des Seienden im Kontext der mittelalterlichen Lichtspekulation, BGPTM NS 18 (Munster: Aschendorff, 1980), pp. 161-165.

51. Scientia Christi 4 (CSB 5:23b); Augustine De Trinitate 14.15.21 (CCSL 50A: 450.35-39).

52. Augustine De Trinitate 14.15.21 (CCSL 50A:451.49-50).

53. Scientia Christi 4 (CSB 5:23b).

54. See Scientia Christi 4 ob. 7-9 and 14 (CSB 5:21b, 22a), together with ad 7-9 and $14(5: 25 a, b)$. 
(ratio superior), will open a way that makes possible a nuanced reply to this question.

We see it in the following three questions, which treat the human knowledge of Christ. We already have a preparatory hint in Bonaventure's reply to the second oppositum. There, in connection with a quotation from Augustine, Bonaventure proposes the claim that if the light of the eternal truth were the standard of knowledge for all true things, no soul would know anything true unless it were pure and holy. Since the consequent is not the case, the antecedent is also denied. ${ }^{55}$ Bonaventure solves this objection by distinguishing between knowledge and wisdom. To be sure, a knower knows by means of the eternal ideas, but not with complete firmness. Only the wise man can do that, since he knows them in peace; the knowledge of the rationes aeternae cannot be taken away from him again. ${ }^{56}$

\section{FROM KNOWLEDGE TO WISDOM}

What is meant by the distinction between knowledge and wisdom? First, we must recall what we said in the overview of the questions with reference to wisdom as the epitome of perfect knowledge. Consider a figure of speech that Bonaventure uses almost universally in this connection: in via in patria. ${ }^{57}$ It would be a mistake to see in this figure of speech only a Christian-soteriological motif. It serves primarily to get a better grasp on the dilemma in the analysis of human knowledge that is also expressed as a distinction between wisdom and knowledge.

In the present state of imperfection we sometimes arrive, in our search for a foundation guaranteeing certainty to our knowledge, at such principles in which the ratio aeterna is recognized only in its generality, as an a priori ground of epistemic certainty, but not in itself. 58 The discursive intellect of the knower thus attains only principles that regulate knowledge, that guarantee no lasting certainty, because they

55. Scientia Christi 4 ob. 2 (CSB 5:21a), together with Augustine De Trinitate 1.2.4 (CCSL 50:31.9-11).

56. Scientia Christi 4 ad 2 (CSB 5:24b).

57. Scientia Christi 4 (CSB 5:24a-b), 6 (5:35a-b), 7 (5:40a), epilogue (5:42b).

58. Scientia Christi 4 ad 16 (CSB 5:25b). 
cannot trace back the knowledge to the ultimate principle. Only in that reductio would our struggle for certain knowledge come to rest and to fulfillment. ${ }^{59}$ Such a knowledge, however, exceeds the domain of discursive reason and reaches an immediate insight into that ultimate principle, which Bonaventure calls interchangeably "eternal standard" (ratio aeterna), "highest truth" (summa veritas), "infallible light" (lux infallibilis), "supreme creative art" (superna ars), and "God." But this perfect knowledge, which both exceeds the natural capacity of the rational soul and perfects its immanent struggle, can no longer be reckoned a part of knowledge in the strict sense. Bonaventure, therefore, speaks of an excessus, an "overstepping" or "exceeding" of knowledge into wisdom. It happens only to a few, to the perfected intellects, "which is why only a few are wise and many can know." 60

Following the twelth-century tradition of so-called speculative mysticism, which is associated with names like Hugh and Richard of St. Victor, ${ }^{61}$ Bonaventure displays in the body of the seventh question six steps of a path from mere belief to perfect comprehension. Perfect comprehension is, of course, reserved for the eternal Trinity. The rational soul reaches the outer limit in insight on the level of overstepping (excedere): it sees God and so arrives at an immediate unitary view of the supreme principle and the highest truth itself, without becoming one with that truth. This is true not only of the case in statu viae where we are moved, enraptured, and lifted up-which signifies each time a special overstepping of the present state-but also of the state of perfection in patria. 62

\section{PERFECT KNOWLEDGE AND CREATED WISDOM}

In the last three questions, Bonaventure opens a second perspective on the understanding of wisdom. The point of departure

59. Scientia Christi 4 ad 19 (CSB 5:26a).

60. Scientia Christi 4 ad 19 (5:26a), 6 (CSB 5:35a). Compare Itinerarium mentis in Deum 1.6 (CSB 5:297b), Collationes in Hexaëmeron 19.3 (CSB 5:420b).

61. See "Kontemplation," LM 5:1414-1416, and "Extase," DS 14:2113-2120.

62. Scientia Christi 4 (CSB 5:24b), 6 (5:35a-b). See also Itinerarium 1.2-6 (CSB 5:297a-b), 7.1 (5:312a); Speer, Triplex veritas, pp. 75-79 and 118-120. Compare "Extase," DS 4:2120-2125. 
for this is an obviously theological one. It begins with Christ's human knowledge, not in its full phenomenological breadth, but rather as it extends to the uncreated wisdom and to everything that Christ can see in that uncreated wisdom. Bonaventure distinguishes created wisdom from this. The distinction follows from the manner of the influence and presence of the supreme light of truth in knowledge that lays claim to certainty. A merely general influence, without the immediate presence of that light, is as obviously insufficient as its mere presence without the possibility of an immediate influence. ${ }^{63}$ This addresses, once again, the problem of the participation of the created souls in the ratio aeterna and their cooperation in the comingto-be of certain knowledge. Bonaventure's answer follows from the line of thinking up to this point, but it expands during the discussion of the extent of human knowledge in the last three questions.

If we know with certainty only when we comprehend all of the conditions of knowledge and possess wisdom, then it cannot be satisfactory to suppose such knowledge exclusively in the state of perfection, for then this insight would run the risk of having the character merely of a provisional, relative truth. Human knowledge, striving after certainty, must also have the ability to extend to that uncreated wisdom, which itself can be reached only by a deiform and ecstatic intellect. The manner in which the created intellect can participate in the uncreated wisdom in statu viae, and at the same time in the "forming, enabling, and uplifting principle," is created wisdom. ${ }^{64}$ According to Bonaventure, the soul of Christ was also, so far as he was a human being, bound to this sapientia creata as a necessary condition of his having wisdom. But this knowledge was at the same time limited, since Christ's soul did not have actual knowledge of everything that it knew as the divine Word. In this way, Bonaventure manages to conform to the teaching of the Council of Chalcedon and to the requirements of the communication of idioms. ${ }^{65}$

This brings us back to the first question: Is the knowledge of Christ, so far as he is the divine Word, really infinite? The background of this question is the doctrine, going back to Augustine, of the origin of being in God's knowledge, in his eternal, uncreated wisdom. In the

63. Scientia Christi 5 (CSB 5:29b).

64. Scientia Christi 5 (CSB 5:30a), 6 (5:34b).

65. Scientia Christi 6 (CSB 5:35a), 7 ad 1-3 (5:40b). Compare Ernst, Erkenntnis Christi, pp. 163-165. 
sixth question too, Bonaventure seizes on the infinite, specifically of infinite truth and goodness which alone can fulfill the understanding and appetite of the rational soul and bring it to rest when the soul is lifted up above its own capacity for understanding. 66

Driven by the goal of knowing the totality of being and of its ultimate ground, the intellectual capacity experiences its limits with all clarity. But the natural limit of creaturely knowledge lies not so much in a limitation on the domain of objects, but rather in the imperfection of that capacity itself, in its limitation to knowing secundum esse, to the knowledge of actual being. By contrast, perfect insight into every structure and condition that determines the universe, knowledge "in accordance with that divine art, through which all things come to be," is denied to the created soul. 67 The reason for this lies in the very nature of knowledge secundum esse, which is determined by five criteria: dominance of the subject of knowledge in the act of knowing, fulfillment of only one domain of the striving after knowledge, discursiveness, the analytic quality of the judgments, and limitation to a finite horizon. In contrast, the exceeding knowledge secundum artem is likewise distinguished by five analogously formulated criteria: dominance of the object of knowledge as the encompassing goal of all knowledge, perfect fulfillment of the entire appetite for knowledge, the abolition of the discursive limitation as well as of the limitation to analytic and synthetic judgments, and finally the directedness to an infinite horizon. 68

It should be pointed out that Bonaventure here defines the meaning of comprehending knowledge (cognitio comprehensiva) and exceeding knowledge (cognitio excessiva) in immediate dependence on pseudoDionysius and, so, in contrast to the scheme of levels in the sixth question, which relies on Augustinian speculative mysticisms. ${ }^{69} \mathrm{With}$ pseudo-Dionysius, Bonaventure describes that exceeding not as transcensus but as excessus. For the subject of knowledge does not outstrip the object of knowledge; rather, the one who has "exceeding" knowledge is brought to the object of knowledge "by going beyond

66. Scientia Christi 6 (CSB 5:35a).

67. Scientia Christi 7 ad 4 (CSB 5:40b-41a).

68. Scientia Christi 7 (CSB 5:40a-b); Speer, Triplex veritas, pp. $80 f$.

69. Compare Scientia Christi 6 (CSB 5:35a) and the preceding section. See further "Kontemplation," LM 5:1414-1416, and "Extase," DS 4:2125-2126. 
himself in a way that exceeds everything, whereby he lifts himself above himself."70

It would be a mistake to see in this determination of the extent of knowledge a boundless epistemological optimism. On the contrary, one sees a string of what are unmistakably epistemological critiques. They hold especially for the knowledge that is founded on reason alone, but also for the possibility of a perfect comprehension of the highest truth on the basis of an acquired and, therefore, created wisdom. Even a supernatural illumination that raised the soul to know things in the eternal divine art would allow it to know the contingent with certainty, but would not effect an actual knowledge of the infinite. Thus, it would not make possible a surpassing of the soul's own finitude. ${ }^{71}$

This is the only explanation of the conclusion of the collection of questions, which had its systematic point of departure in the question of the knowledge of the infinite. In the epilogue, Bonaventure summarizes the line-of-thought of the seven questions in order to draw out what might seem at first a surprising conclusion. The insight into the process of knowledge that he has won, which culminates in surpassing, in exceeding (excessus), as the utmost and most excellent manner of knowing, leads Bonaventure to the conclusion that negative propositions are more suitable than affirmative, exceeding predications (superpositiones) than positive predications (positivae praedicationes), in grasping this true wisdom. Quite in the spirit of Dionysian negative theology and with an appeal to the writings of the alleged disciple of the Apostle Paul, Bonaventure points out that "an inner silence can lead to that experience more than an external word."72

\section{THE PERSPECTIVE OF METAPHYSICS}

Reflection on the conditions of epistemological certainty and on the extent of our knowledge remain, for Bonaventure, determining motifs even in his later works. This is true, for example, in a

70. Scientia Christi 7 (CSB 5:40a).

71. Scientia Christi 7 ad 11 (CSB 5:41b).

72. Scientia Christi epilogue (CSB 5:43b). 
scientific-theoretical perspective of De reductione artium ad theologiam, which also derives from Bonaventure's lecturing activity in 12551257. It holds as well for the Itinerarium mentis in Deum, which appeared around the end of 1259. The Itinerarium further develops the central thoughts of his epistemology and metaphysics very much in the tradition of speculative mysticism. ${ }^{73}$

When these writings appeared, Bonaventure had already left his teaching position in Paris, having been elected Minister-General of the Friars Minor on February 2, 1257. He faced the difficult task of consolidating an order that, given the numbers of its members, still had only a negligible organization. But Bonaventure stopped in Paris on several later occasions. The three sermon series in particular, which he gave in the Franciscan convent there in 1267 (De decem praeceptis), 1268 (De donis Spiritus Sancti), and 1273 (Collationes in Hexaëmeron), confirm his unbroken interest in the intellectual life at Paris, as they show his attempt to tie the Franciscan movement more strongly to the intellectual developments of its time. ${ }^{74}$ This important feature of his work often falls completely into oblivion. It is displaced by a spiritual interpretation in the support of a "Franciscan option" or a "théologie du pauvre." 75 For our point of view, it is telling that Bonaventure-like Thomas Aquinas who also returned to Paris, presumably in 1269 , on commission by the general chapter of his order-intervenes anew in current doctrinal controversies in what remains the most significant university, controversies again excited by Aristotelianism. ${ }^{76}$ The problems, of course, had changed. At the beginning of his studies, the reception of the libri naturales of Aristotle, as well as questions about the speculative penetration of the contents of faith, had stood in the center of the dispute. In the meantime,

73. See Bougerol, Introduction, pp. 7, 215-220; Speer, "Wissenschaft und Erkenntnis," pp. 180-184; and Speer, "Metaphysica reducens: Metaphyik als erste Wissenschaft im Verständnis Bonaventuras," RTAM 57 (1990): 161-165.

74. Bougerol, Introduction, pp. 227-241.

75. Speer, "Metaphysica reducens," pp. 143-145, in contrast with Werner Dettloff, "Die franziskanische Vorentscheidung im theologischen Denken des heiligen Bonaventura," Münchener Theologische Zeitschrift 13 (1962): 107-115, and Bougerol, Introduction, pp. 12-30 and 283-288.

76. Van Steenberghen, La philosophie au XIIle siècle, pp. 427-430, following the general overview on pp. 411-426. 
the works of Aristotle had at last found a secure place in university instruction and had been commented upon thoroughly in all their extent, especially by Albert the Great.

Now the question was how philosophical and theological truth are related to each other. More precisely, it was how the truth of the sciences could stand to the truth of a theology that was, by this time, equally regarded as science. This conflict caught fire particularly on the questions of the individuality of the intellectual soul and the eternity of the world. The questions were answered by Parisian masters like Siger of Brabant and Boethius of Dacia, who appeal to Averroës in support of a radical Aristotelianism. They call into question the synthesis achieved in different ways by Thomas and Bonaventure. 77 With them, metaphysics begins to develop as a science of first principles founded in reason alone: it enters into competition with theology, which takes its first principles from revelation. Consequently, metaphysics stood in need of a justification of its knowledgeof-principles with regard to revelation, and, conversely, the theology of revelation-principles had to be shown to be possible and necessary with regard to the philosophi. 78

Against the background of this controversy, Bonaventure by no means adopts an anti-philosophical attitude, as he is sometimes reproached for doing. The conviction of the necessity of an explanation that rests on reason, which stamps the collection of questions dating from his earlier teaching activities, also determines his last sermon series on the Hexaemeron. With it, Bonaventure joins an old tradition of commentary. Reacting against the model of Aristotelian metaphysics, he formulates his criteria for a metaphysics that can make good on the claim of metaphysics to be a science that proceeds from the knowledge of principles and the ultimate foundation. Metaphysics

77. Van Steenberghen speaks both of "Aristotélisme hétérodoxe" and of "Averroisme" in La philosophie au XIIle siecle, pp. 357-412. On the doctrinal controversy, see pp. 413-471.

78. Ludger Honnefelder, "Der zweite Anfang der Metaphysik: Ansätze und Folgen der Wiederbegründung der Metaphysik im 13./14. Jahrhundert," in Philosophie im Mittelalter: Entwicklungslinien und Paradigmen, ed. J. P. Beckmann et al. (Hamburg, 1987), pp. 165-168; Albert Zimmermann, Ontologie oder Metaphysik? Die Diskussion über den Gegenstand der Metaphysik im 13. und 14. Jahrhundert, STGM 8 (Leiden and Cologne: Brill, 1965), p. 90. 
must bear in mind the emanation, exemplarity, and consummation of reality, and bear them in mind according to the degree of illumination and in the manner of a reductio to knowledge of principles. ${ }^{79}$

Nevertheless, Bonaventure keeps in view the limits on the scope and certainty of rational knowledge. To be sure, metaphysics is for him the science of being and its principles. Nonetheless, Bonaventure disputes a broader claim of metaphysics on the way toward a critique of metaphysics that he also executes as a critique of reason. ${ }^{80}$ Every science based on reason is under the verdict of fallibilism. It is also true of metaphysics, which is distinguished from an ultimate foundation based on revelation.

Although Bonaventure, once again, underscores the finitude of human knowledge, he does not mean to deny the object-related use of reason where this is required. In Bonaventure's eyes, there opens up a wide field of positive autonomy of scientific rationality, which he undoubtedly acknowledges and by which he-true child of his timefeels challenged. Although he clings more tenaciously than many of his contemporaries to the Augustinian ideal of a comprehensive Christian wisdom, and, thus, to the fundamental desire for a single knowledge, he cannot ignore from the outset the confrontation with the claim of the sciences to explain consistently the connections of reality. ${ }^{81}$

\section{CONCLUSION}

I should like to close with two observations that relate to the twofold aspect of this essay expressed at the beginning: to treat one of the great themes of philosophy by looking at a medieval author whose contribution to the philosophical discussion of the time is, in general, judged with reserve.

The first observation is intended to hold for the historical evaluation. We were able to see the background against which Bonaventure

79. Coll. in Hexaëmeron 1.17 (CSB 5:332b).

80. Compare Coll. in Hexaëmeron 12.12 (CSB 5:386a).

81. Speer, "Metaphysica reducens," pp. 172-182; Van Steenberghen, La philosophie au XIIle siècle, pp. 197-200. 
develops his epistemological inquiries, the background of contemporary controversies as well as of the tradition preceding Bonaventure. Both backgrounds must be considered in discerning what determines Bonaventure's question and his answer. In this sense, the historical procedure is the necessary condition for philosophical understanding; indeed, of any understanding whatever. The same is true of Bonaventure himself, for the specific appropriation of traditions, the engagement with their pre-understanding, is the condition for anything whatever being understood, for there being any questions. Etienne Gilson speaks of an "Aristotelianizing Augustinianism," and Fernand van Steenberghen, on the contrary, of an "eclectic and neo-Platonizing Aristotelianism." 82 But any such schematizings of Bonaventure betray his appropriation of traditions, which proves to be much more nuanced and topical. His appropriation depends on the question at hand, for which a given tradition may or may not offer a model answer.

Among these traditions, the triplet of Augustine, pseudo-Dionysius, and Aristotle stands out. We can show that Bonaventure is most conversant with the Aristotelian writings, not only by the multitude of explicit and implicit references, but also, for example, by his interest in the new and more exact translations of Aristotle, such as the nova translatio of the Nichomachean Ethics by Robert Grosseteste. ${ }^{83}$ Reference has already been made to Bonaventure's thorough engagement with Aristotelian positions, especially in the fourth question. With Augustine and the pseudo-Dionysian corpus, Bonaventure appeals to the two most influential traditions of Christian reception and transformation of Platonic and neo-Platonic intellectual riches. Their diverse character is reflected clearly in the actual systematic context in which Bonaventure makes use of their arguments. Thus, we find in connection with the question of the unity and the outer limit of knowledge-especially in the last three questions, but also in the third question-multiplied references to the Dionysian concept of negative theology. Yet Bonaventure develops his epistemological position and exemplarist ontology on the foundation of Augustine's

82. Gilson, La philosophie de saint Bonaventure, pp. 390-395; Van Steenberghen, La philosophie au XIIle siècle, pp. 15-18 and 246-267.

83. Compare Scientia Christi 4 arg. 16 (5:18b). On the Aristotelian sources, see the survey by Bougerol, "Saint Bonaventure et Aristote," AHDLMA 40 (1973): 135-222. 
affirmation of conceivability, modified by the aforementioned influence of Aristotle.

Or does Bonaventure's epistemological problematic result entirely from the answers that he finds ready-made in the traditions? It is not only the working out of particular individual problems in particular tradition-contexts that suggests such a consideration. The question extends further. In the example of the problem of certainty, it becomes clear that Bonaventure's twofold requirement for certainty on the side of both the object and the subject of knowledge, his connecting of a priori and a posteriori elements in the analysis of knowledge, arises out of an intense confrontation with Augustinian and Aristotelian elements. Here lies Bonaventure's unique contribution.

That brings me to my second observation, which has to do with the systematic meaning that I have claimed for Bonaventure's answer. Is there a conceivable aspect under which Bonaventure's reflections can be answers to today's questions? Such a possibility is, as a rule, widely excluded especially for medieval authors, often by means of an appeal to the so-called transcendental turn in philosophy, behind which no road leads back. But can the reproach that has been made against "pre-critical" metaphysics, that it mistakenly seeks to explain the world that exists only in appearance as "real," give itself any other foundation than to be again merely an appearance? If not, then it stands under the same proviso, that it is merely one interpretation of reality that can establish itself in the face of other interpretations only by being a plausible answer to recent questions. More precisely, the focus of understanding is that my questions find an answer. ${ }^{84}$

This line of argument of recent philosophizing is found, in another form, within Bonaventure. More strongly than many of his contemporaries he reflects on the limits of philosophical knowledge. He sees the finitude of pure reason. In this sense, all rational knowledge is provisional. It stands, to put it theologically, under an eschatalogical reservation. ${ }^{85}$ For Bonaventure, this is true quite literally. Here I have come to the decisive point. The fact that our understanding is only an interpretation of reality is represented by Bonaventure in the manner

84. Compare Josef Simon, Philosophie des Zeichens (Berlin and New York: W. de Gruyter, 1989), pp. 13 and 170-174.

85. Compare Collationes de septem donis Spiritus sancti, especially 4 (CSB 5:473$479)$ and 8 (5:493-498). On this point, see also Speer, Triplex veritas, pp. 123-126. 
of a theological critique of philosophy. 86 A renewed parallel appears: the eschatological perfection of the striving after knowledge is not thought of in the sense of scientific generality, as if it were possible to win an "objective" standpoint outside history. It is conceived as the individual coming-to-an-end of questioning and striving. But at that point all discourse is over. We understand without questioning. ${ }^{87}$

Universität $z \mathfrak{u}$ Köln

86. Compare Coll. in Hexaëmeron 4.1 (CSB 5:349a), 5.2 (5:357b). On the "tenth Science," which philosophy sought in vain, see Speer, "Metaphysica reducens," p. 179. 87. Compare Scientia Christi epilogue (CSB 5:43b); Itinerarium 1.2-6 (5:297a-b), 7.1 (5:312a-b). See also Simon, Philosophie des Zeichens, pp. 39f and $152 \mathrm{f}$. 